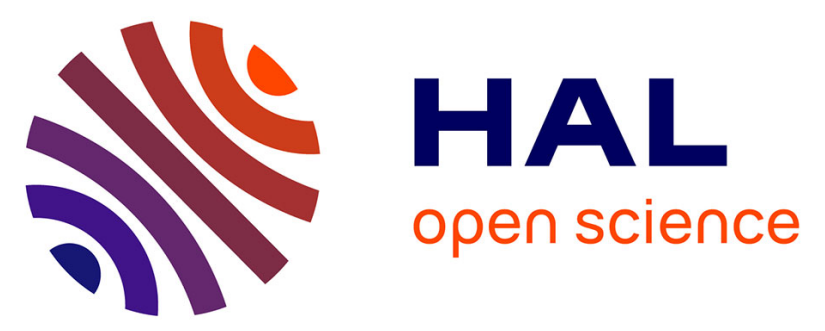

\title{
Freshwater sediment pesticide biodegradation potential as an ecological indicator of microbial recovery following a decrease in chronic pesticide exposure: A case study with the herbicide diuron
}

\author{
S. Pesce, C. Margoum, N. Rouard, A. Foulquier, F. Martin Laurent
}

\section{To cite this version:}

S. Pesce, C. Margoum, N. Rouard, A. Foulquier, F. Martin Laurent. Freshwater sediment pesticide biodegradation potential as an ecological indicator of microbial recovery following a decrease in chronic pesticide exposure: A case study with the herbicide diuron. Ecological Indicators, 2013, 29, p. 18 p. 25. 10.1016/j.ecolind.2012.12.014 . hal-00811538

\author{
HAL Id: hal-00811538 \\ https://hal.science/hal-00811538
}

Submitted on 10 Apr 2013

HAL is a multi-disciplinary open access archive for the deposit and dissemination of scientific research documents, whether they are published or not. The documents may come from teaching and research institutions in France or abroad, or from public or private research centers.
L'archive ouverte pluridisciplinaire HAL, est destinée au dépôt et à la diffusion de documents scientifiques de niveau recherche, publiés ou non, émanant des établissements d'enseignement et de recherche français ou étrangers, des laboratoires publics ou privés. 
Ecological Indicators - Volume 29, June 2013, Pages 18-25

http://dx.doi.org/10.1016/j.ecolind.2012.12.014

\title{
Short Communication \\ Freshwater sediment pesticide biodegradation potential as an ecological indicator of microbial recovery following a decrease in chronic pesticide exposure: A case study with the herbicide diuron
}

Stéphane Pesce*a ${ }^{\text {a }}$ Christelle Margoum ${ }^{\mathrm{a}}$, Nadine Rouard ${ }^{\mathrm{b}}$, Arnaud Foulquier ${ }^{\mathrm{a}}$, Fabrice MartinLaurent ${ }^{\mathrm{b}}$, E-mail the corresponding author

a Irstea UR MALY, 5 rue de la Doua, CS 70077, 69626 Villeurbanne Cedex, France

b INRA, UMR 1347 Agroecologie, 17 rue Sully, B.P. 86510, 21065 Dijon Cedex, France

* corresponding author

\begin{abstract}
The aim of this study was to evaluate the use of freshwater sediment biodegradation potential as an ecological indicator for monitoring microbial recovery following a decrease in chronic pesticide exposure. For this purpose, a four-year case study (2008-2011) was conducted in a small stream (Morcille river) long exposed to high diuron concentrations, increasing from upstream to downstream. Our results show that the ban on diuron in December 2008 resulted in a progressive decrease in its concentrations in the Morcille river over the survey period. However, diuron remained present in the water three years after the ban. The spatio-temporal variations in the sediment biodegradation potential were assessed by radiorespirometry using [ring-U-14C] diuron to estimate diuron mineralization potentials. Between autumn 2008 and autumn 2011, mean diuron mineralization percentage after 15 weeks of incubation decreased by $65 \%$ downstream and by $82 \%$ in the intermediate sector, and mean $10 \%$ diuron dissipation time values increased between $143 \%$ (downstream) and $210 \%$ (intermediate). Thus the decrease in the level of chronic diuron exposure in the river also caused a fall in sediment diuron-mineralizing capacities, revealing a corresponding recovery of microbial communities. Our results show that the use of freshwater sediment biodegradation potential may be useful for assessing microbial recovery after a decrease in chronic exposure to pollutants, opening prospects for developing a new class of ecological indicator to monitor the recovery of biological quality of water resources. In this way, the use of molecular approaches based on direct extraction of nucleic acids from environmental matrices and their subsequent analysis by PCR-based approaches to quantify the abundance of pesticide-degrading communities could represent a promising alternative.
\end{abstract}

\section{Highlights}

- We performed a 4-year survey in a river long exposed to diuron. The ban on diuron resulted in a gradual fall in its concentrations in the river. Sediment diuron biodegradation potential decreased throughout the survey. Degradation capacities can be an ecological indicator to gauge microbial recovery.

\section{Keywords}

Biological monitoring;

Microbial communities;

Mineralization;

Vineyard;

Water Framework Directive 


\section{Introduction}

Water resources and aquatic ecosystems are an essential concern of any policy for sustainable development. European Water Framework Directive (WFD, 2000) is aiming to achieve good chemical and ecological status of waters by 2015. The European Commission was required to come forward with specific legislation regulating in more detail the general requirements of the Water Framework Directive in relation to chemical pollutants. In accordance with Article 16 of the WFD, the European Union drawn up a list of 33 priority substances representing a significant risk to or via the aquatic environment. Most of these substances are synthetic contaminants, including pesticides (Coquery et al., 2005). Nearly all of the pesticides listed have since then been prohibited for use in several European states. For example, the herbicide diuron (3-(3,4-dichlorophenyl)-1,1-dimethylurea, Bayer CropScience) was banned in France in December 2008 (French Republic Official Journal No. 204; 04.09.2007) in application of the EC directive 2007/417/EC.

Diuron is a phenylurea herbicide used for total control of weeds and mosses. This pesticide inhibits photosynthesis by blocking electron transfer in photosystem II of plants and photosynthetic microorganisms (Wessels and Van der Veen, 1956). Its intensive use in urban and agricultural areas during the recent decades has led to frequent surface water contamination, as confirmed by several recent studies highlighting the presence of diuron in various rivers draining agricultural watersheds (e.g. Pesce et al., 2008a, Schuler and Rand, 2008 and Stork et al., 2008). There is now evidence from many experimental studies that environmentally realistic concentrations of diuron (i.e. a few micrograms per liter) can affect freshwater microbial communities, including the autotrophic (see for review, Pesce et al., 2011a) and heterotrophic (Pesce et al., 2008b, Tlili et al., 2008, Tlili et al., 2010, Ricart et al., 2009 and Tadonléké et al., 2009) compartments.

In lotic ecosystems, benthic microbial assemblages are now considered as useful potential indicators of ecological status because they integrate the effects of multiple anthropogenic disturbances and have strong capacities to adapt to novel environmental conditions (Burns and Ryder, 2001 and Sabater et al., 2007). Field studies have thus revealed that in situ diuron exposure can induce microbial adaptation leading to an increase in diuron tolerance in phototrophic biofilm communities (Dorigo et al., 2007, Pesce et al., 2010a and Roubeix et al., 2011) and an increase in diuron biodegradation potential of heterotrophic biofilm and sediment communities (Pesce et al., 2009). These studies clearly provide evidence that adaptation to biodegradation is strongly driven by exposure of microbial communities to diuron. It suggests that such approaches could offer a powerful ecological indicator for monitoring spatio-temporal variations in pesticide contamination and evaluating associated ecological effects.

In this context, our main purpose was to evaluate the use of freshwater sediment pesticide biodegradation potential as an ecological indicator to estimate microbial recovery following a decrease in diuron contamination. To this end, we conducted a four-year field survey (20082011) in a small stream (Morcille river, French Beaujolais area) chronically exposed to synthetic and mineral pesticides, applied to vineyards occupying $79 \%$ of the total watershed area $(8.5 \mathrm{~km} 2)$. This site was chosen because numerous studies have shown that before its ban, diuron was the most frequently detected pesticide in the Morcille river, where it displays a gradient of contamination running upstream to downstream (e.g. Montuelle et al., 2010 and Rabiet et al., 2010). Accordingly, it was expected than the ban of diuron would have led to a sharp decrease in its concentrations in the contaminated sections of the Morcille river. We thus hypothesized that in response to the decrease in diuron exposure a decrease of diuron biodegradation potential of the Morcille's sediments would occurred. 


\section{Materials and methods}

\subsection{Study site and sampling procedure}

Samples of sediments (for radiorespirometry analysis) and water (for chemical analysis) were collected at three sampling stations (Fig. 1) located along the Morcille river (southeastern France, Beaujolais area; longitude $4^{\circ} 60^{\prime} \mathrm{E}$, latitude $\left.46^{\circ} 15^{\prime} \mathrm{N}\right)$.

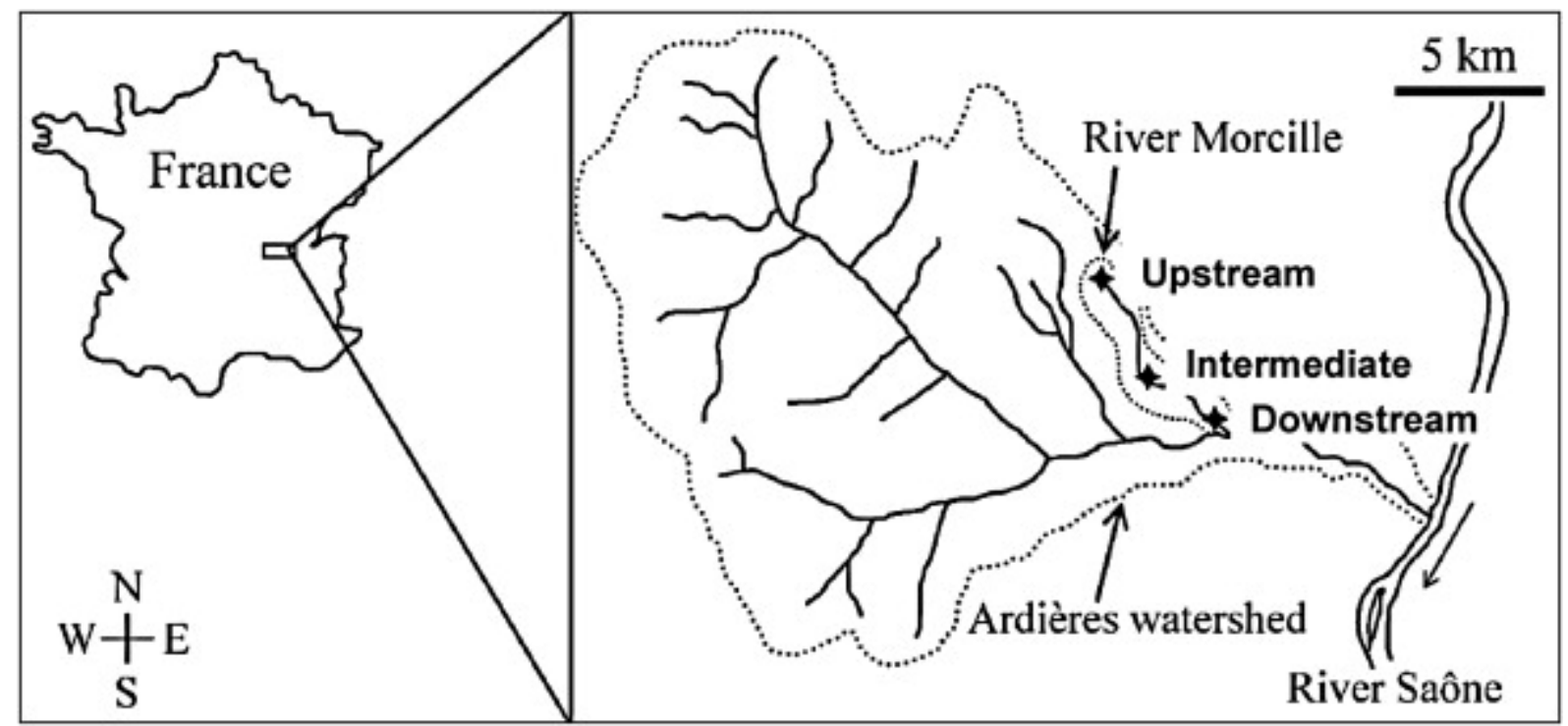

Fig. 1. Location of sampling stations along the Morcille river (Beaujolais area, France)

At each sampling station (upstream, intermediate and downstream, respectively), a composite sediment sample of the upper layer horizon $(0-5 \mathrm{~cm}$; about $500 \mathrm{~g})$, made up of five randomly chosen subsamples, was collected three times per year from October 2008 to October 2011. Samples were taken in mid-October (autumn samples), mid-March (spring samples) and midJune (summer samples). These three periods were chosen according to the agricultural practices in vineyard plots so as to collect sediments before (March), during (June) and after (October) the main period of herbicide application over the Morcille watershed.

Water samples $(1000 \mathrm{~mL})$ were collected once a month from January to June 2008 and then twice a month from July 2008 to December 2011 at the three sampling stations to determine diuron concentrations in the dissolved phase.

\subsection{Diuron analysis}

Diuron concentrations in the water phase were determined by solid-phase extraction on Oasis HLB cartridges (60 mg, $3 \mathrm{~mL}$, Waters, France) followed by liquid chromatography-tandem mass spectrometry (LC/MS/MS) with a 1100 LC Series instrument (Agilent, France) coupled to a triple quadrupole mass spectrometer (API 4000, AB Sciex, France). Chromatographic separation was achieved using an Atlantis T3 analytical column $(2.1 \mathrm{~mm} \times 100 \mathrm{~mm}$, particle size $3 \mu \mathrm{m}$ ) from Waters (France), at a flow rate of $300 \mu \mathrm{L}$ min-1 and with a mobile phase gradient of acidified acetonitrile (SDS, France) and ultrapure water (from Millipore system). Injection volume was $20 \mu \mathrm{L}$. Detection and quantification were performed in multiple reaction monitoring (MRM) mode. Concentrations were determined with internal standard calibration curves using Diuron-d6 as internal standard, and were systematically corrected with corresponding surrogate recovery. The quantification limit of diuron was $0.01 \mu \mathrm{g} \mathrm{L}-1$, with a concentration factor of 1000 . 


\subsection{Estimation of diuron mineralization potential}

The ability of sediments to mineralize diuron was determined by radiorespirometry (Soulas, 1993) as described in Pesce et al. (2009). Briefly, sediment samples (10 g dry weight equivalent) were immersed in $50 \mathrm{~mL}$ of mineral water (Volvic, Danone, France) and treated with uniformly [14C-U-ring] diuron (specific activity $567 \mathrm{MBq} / \mathrm{mmol}$; radiochemical purity 99\%; Sigma Aldrich) to reach a final diuron concentration of $10 \mu \mathrm{g} \mathrm{L}-1$ in the water. Triplicates were incubated in the dark at $20{ }^{\circ} \mathrm{C}$ for about 16 weeks. At least once a week, sodium hydroxide-trapped 14CO2 evolved from [14C-U-ring] diuron was analyzed by liquid scintillation counting using ACS II scintillation fluid (Amersham).

2.4. Data processing and statistical analysis

Diuron 10\% dissipation time (DT10) was estimated by fitting a log-normal regression model onto diuron mineralization kinetics (Pesce et al., 2010b). A three-way analysis of variance (ANOVA) was used to assess differences in DT10 and mineralization percentage after 15 weeks of incubation (MP15) between stations, years and seasons. When a significant effect was observed, post hoc comparisons of means were conducted with a Tukey's Honest significant difference test. Significance for all statistical tests was accepted at $p<0.05$.

\section{Results and discussion}

\subsection{Can upstream sediments be taken as reference samples?}

In the context of the European Water Framework Directive (WFD, 2000), restoring chemically contaminated aquatic ecosystems has become an important concern, prompting growing interest in studying recovery trajectories and community resilience in aquatic environments. With this in mind, our main purpose was to evaluate the possible use of freshwater sediment biodegradation potential as an innovative ecological indicator for monitoring microbial recovery following a decrease in diuron exposure. In a first step, we emphasized the selection of reference sites, which is crucial to using biological indicators of ecological status (Delgado et al., 2012). The upstream section of the Morcille river was proposed as a reference site, because of repeated reports over the years showing a marked pollution gradient for the herbicide diuron from up- to downstream (e.g. Montuelle et al., 2010 and Morin et al., 2010).

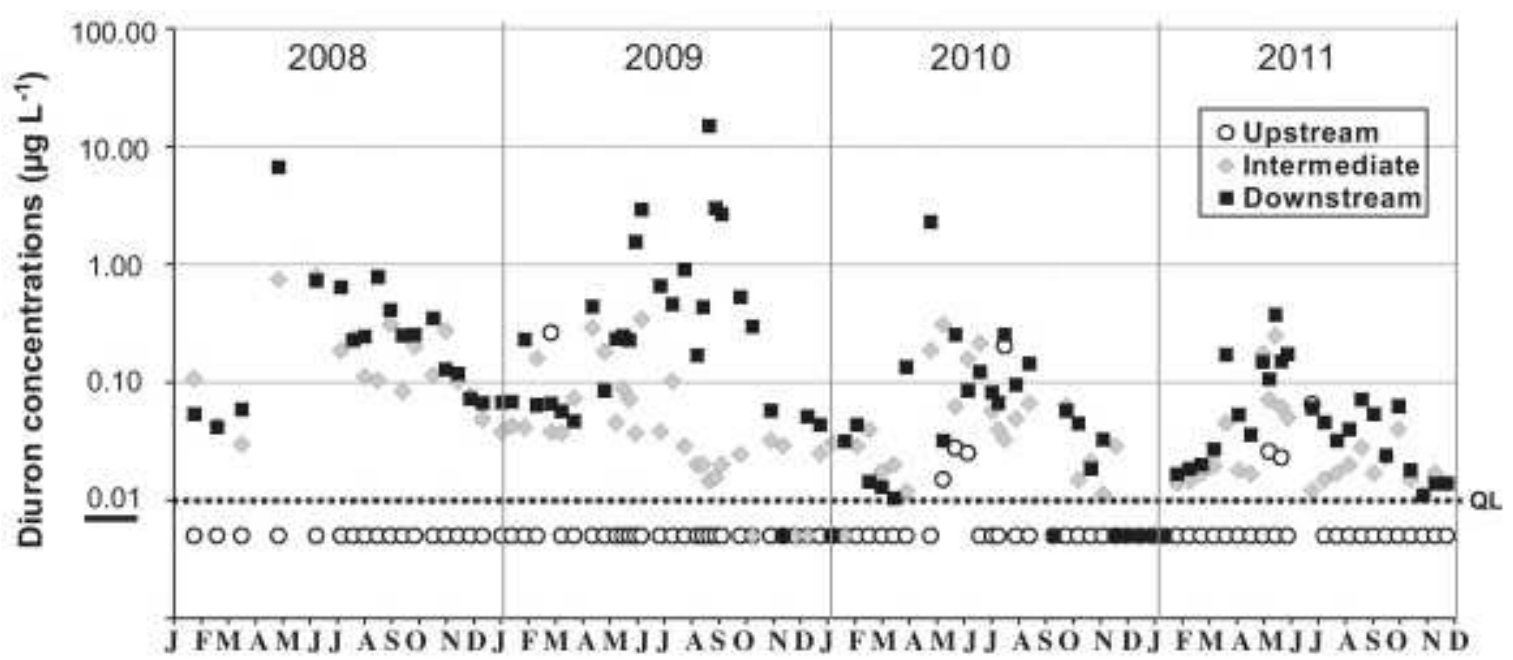

Fig. 2. Diuron concentrations ( $\mu$ g $L-1)$ measured in water samples collected at upstream, intermediate and downstream stations over a four-year survey period. Values under $0.01 \mu \mathrm{g}$ L-1 were below the quantification limit $(\mathrm{QL})$, and so diuron concentrations could not be determined. Letters on the horizontal axis indicate the month of the year. 
To validate this proposal, diuron concentration and diuron mineralization potential were monitored respectively in water and sediment samples collected upstream in the Morcille river over the four-year survey. As expected, diuron concentrations measured in water samples collected upstream were very low, with $92 \%$ of the recorded concentrations below the quantification level $(0.01 \mu \mathrm{g} \mathrm{L}-1)$. Over the four-year survey, only two samples collected upstream showed concentrations slightly higher than the environmental quality standards (EQSs) for all surface waters covered by the WFD $(0.2 \mu \mathrm{g} \mathrm{L}-1$; substance data sheet for priority substance No. 13: Diuron, CAS No. 330-54-1) and the potability limit fixed by the EU (0.1 $\mu \mathrm{g} \mathrm{L-1)} \mathrm{(Fig.} \mathrm{2).}$

In parallel, sediments collected upstream in the Morcille river showed a low mineralization potential (Fig. 3) with mineralization percentage after 15 weeks of incubation (MP15) between $10 \%$ and $20 \%$ of initially added [14C-U-ring]diuron, with only slight variations between seasons or between years (Fig. 4). However, we noted an exception in summer 2009 for one replicate of the upstream sediment sample. In addition, diuron $10 \%$ dissipation times (DT10) were also relatively constant over time at the upstream station (Fig. 5), with mean values between about 85 days (summer 2009) and 140 days (autumn 2009). It has been shown that the development of pesticide biodegradation capacities in natural microbial communities, in both soils (e.g. Sørensen et al., 2003, Dellamatrice and Monteiro, 2004 and El-Sebai et al., 2005; for phenylurea herbicides) and sediments (Toräng et al., 2003, Pesce et al., 2010b and Trinh et al., 2012) occurs in response to repeated exposure to pesticide. The stable, low mineralization potential observed upstream thus clearly reflected the steady low level of diuron exposure recorded in this river section during the four-year survey period.

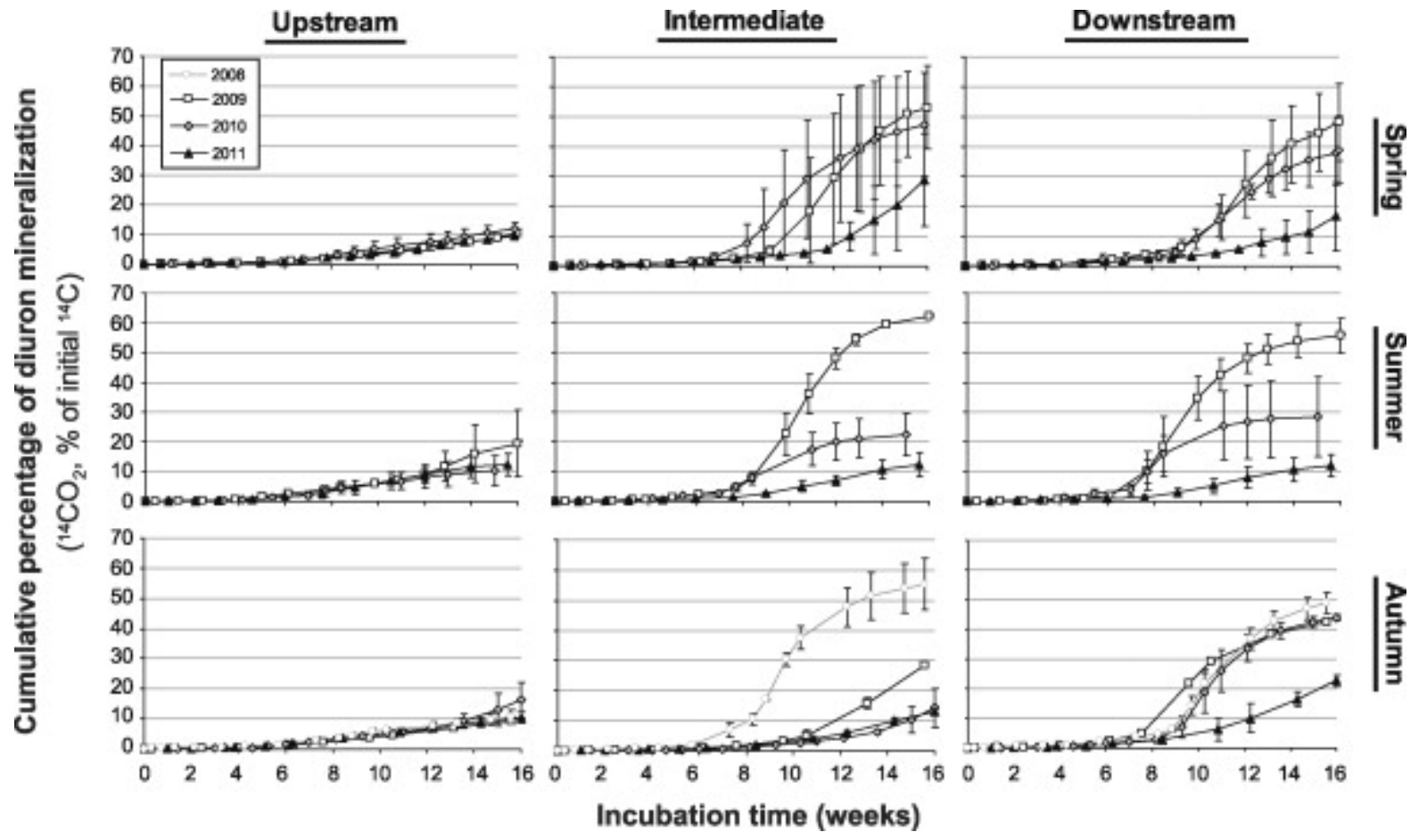

Fig. 3. Time-course of diuron mineralization (mean \pm standard deviation; $\mathbf{n}=3$ ) recorded for sediments collected at the upstream, intermediate and downstream stations over a four-year survey. Evolution of $14 \mathrm{CO} 2$ from [14C-U-ring] diuron was monitored throughout a 16-week incubation period in microcosms by scintillation counting and is expressed in percentage of initial radioactivity added to the sediment microcosms. 


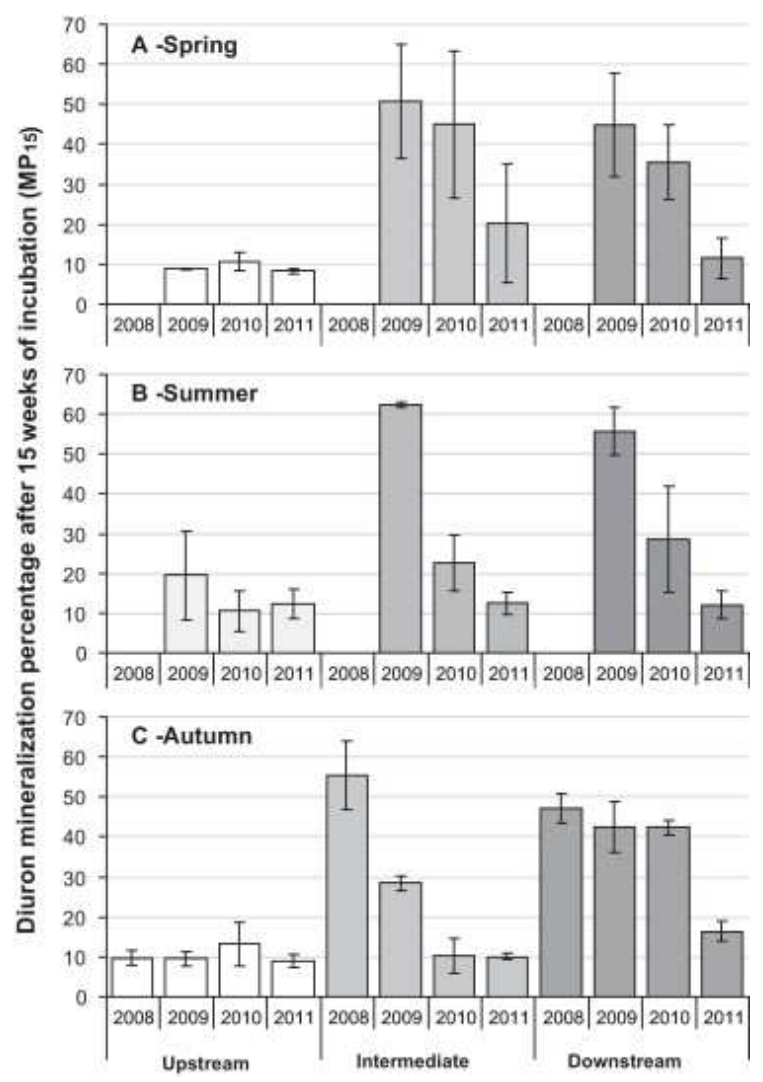

Fig. 4. Diuron mineralization percentage after 15 weeks of incubation (MP15) recorded in microcosms for sediments collected at the upstream, intermediate and downstream stations over a four-year survey (mean \pm standard deviation; $n=3$ ).

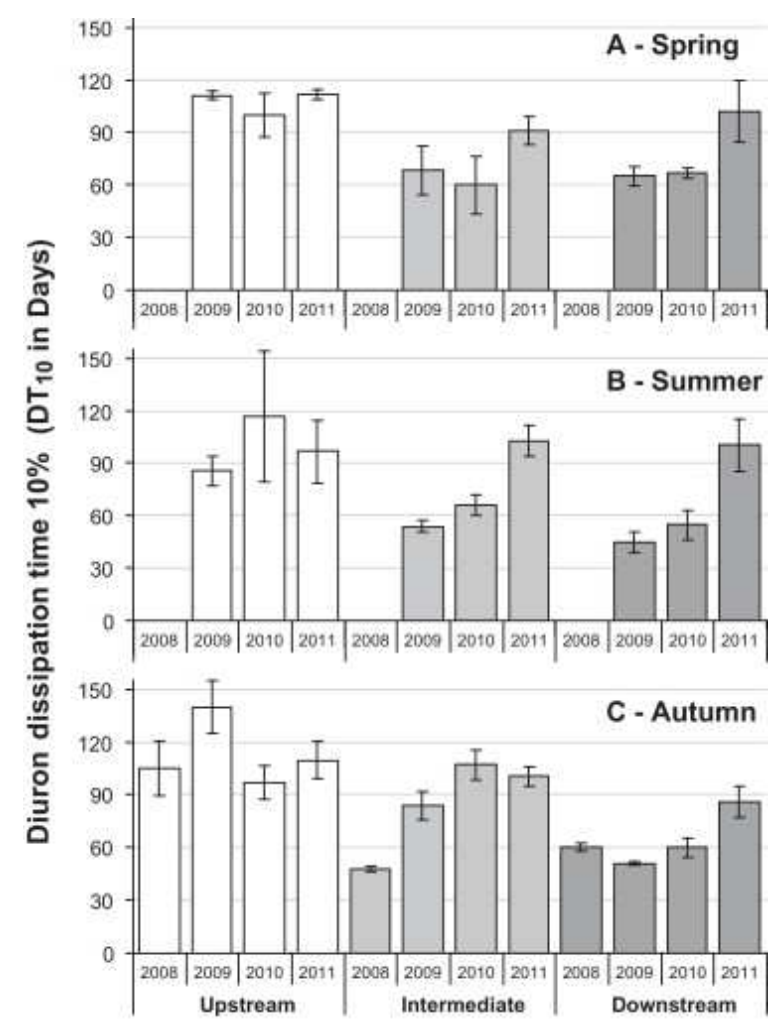

Fig. 5. Diuron 10\% dissipation time (DT10) recorded in microcosms for sediments collected at the upstream, intermediate and downstream stations over a three-year period (mean \pm standard deviation; $n$ =3). 
In addition, and interestingly, the mineralization kinetics obtained with upstream sediments in this study (Fig. 3) were quite similar to those obtained, following the same protocol, with sediments collected in June 2007 (Pesce et al., 2009) and February 2008 (Pesce et al., 2010b) at the same sampling site. This temporal stability over seasons and years further strengthens the reproducibility of the observations reported here, and justifies the use of the upstream sediments as reference in the present study.

\subsection{Did the potential of the Morcille sediments for the mineralization of diuron observed before its ban reflect their exposure level to this herbicide?}

In autumn 2008, just before the interdiction of diuron, upstream sediments exhibited lower mineralization potential than intermediate and downstream sediments, with MP15 (Fig. 4) and DT10 values (Fig. 5) respectively 5 times lower and 2 times higher in the reference station. This was confirmed by the three-way ANOVA, which indicated significant differences between stations in MP15 (F2,22 = 17.17, p < 0.001) and DT10 (F2,22 = 14.48, p < 0.001) values. Post hoc comparisons indicated that MP15 and DT10 were respectively significantly lower and higher at the upstream station $(p<0.05)$ than at the intermediate and downstream stations. The gradual increase in mineralization capacities along the Morcille river from up- to downstream was concomitant with the increase in diuron concentrations. In the three months preceding sediment samplings in autumn 2008, diuron concentrations recorded in water samples collected at the reference station $(<0.01 \mu \mathrm{g} \mathrm{L}-1)$ were always lower (Fig. 2) than those collected at the intermediate or downstream stations contaminated with diuron concentrations between 0.1 and $0.4 \mu \mathrm{g} \mathrm{L}-1$ and 0.2 and $0.8 \mu \mathrm{g} \mathrm{L}-1$, respectively (Fig. 6D). In summer 2007, a similar gradual increase in diuron mineralization potential along the Morcille river was reported, with higher diuron-mineralizing ability observed in the downstream section of the river for both periphytic biofilm and sediment communities (Pesce et al., 2009). It is noteworthy that studies on the potential of natural freshwater sediments to degrade synthetic pesticides are scarce ( Kalsch et al., 1998, Larsen et al., 2000, Toräng et al., 2003 and Trinh et al., 2012), but there is now convincing evidence that the capacity of microbial sediment communities to biodegrade these contaminants can increase after an in situ longterm pre-exposure to these compounds ( Toräng et al., 2003 and Trinh et al., 2012).

In the present study, the estimation of diuron-mineralizing ability in the sediments of the Morcille river differentiated the reference (upstream) from the two (intermediate and downstream) exposed stations. This interesting finding suggests that this biological parameter could be a useful indicator to determine earlier diuron exposure of sediments.

\subsection{Did the ban of diuron lead to a decrease in the exposure level in the Morcille?}

In the last decade, several studies have reported long-term chronic contamination of the Morcille river with diuron (e.g. Montuelle et al., 2010 and Rabiet et al., 2010) with concentrations sometimes higher than $10 \mu \mathrm{g} \mathrm{L}-1$ in the downstream section (Pesce et al., 2009). In 2008, diuron concentrations were always higher than the detection limit of $0.01 \mu \mathrm{g}$ L-1 in the intermediate and downstream sections (Fig. 2), with median values of about 0.11 $\mu \mathrm{g} \mathrm{L}-1$ and $0.25 \mu \mathrm{g} \mathrm{L}-1$, respectively (data not shown). A slight decrease in diuron concentrations was observed at the intermediate station between 2008 and 2009, as shown with median annual concentrations $(0.04 \mu \mathrm{g} \mathrm{L}-1$ in 2009; Fig. 6A). This decreasing trend at the intermediate station was confirmed over time and persisted until the end of the survey, whatever the period of the year (Fig. 2 and Fig. 6). As a consequence of this progressive decrease, the median annual concentration fell below $0.02 \mu \mathrm{g} \mathrm{L}-1$ in 2011 (Fig. 6A). 


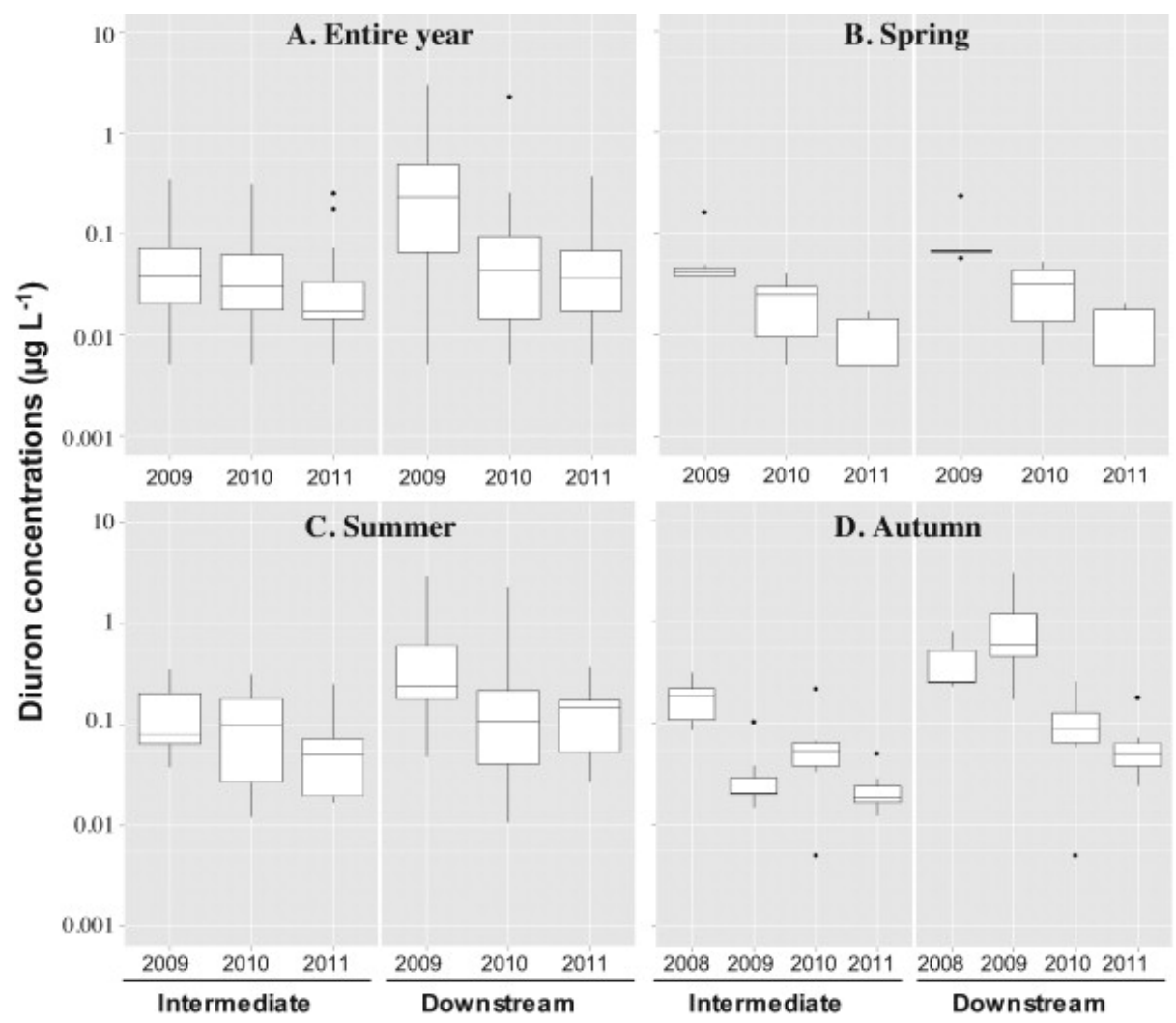

Fig. 6. Boxplot of diuron concentrations measured at the intermediate and downstream stations during the entire years 2009, 2010 and $2011(\mathrm{~A} ; \mathrm{n}=24)$ and during the three months preceding the sediment samplings performed in spring $(B ; 2009-2011 ; n=7)$, summer $(C 2 ; 2009-2011 ; n=7)$ and autumn (D; 2008-2011; $n=7$ ), respectively. The horizontal line represents the median. The upper and lower limits of the box represent the 75 th and 25 th percentiles. The vertical lines above and below the box indicate the range of observed values within 1.5 times the interquartile range from the 75 th and 25 th percentiles. Values outside this range are considered as outliers and are indicated as points.

A similar downward trend was observed at the downstream station, but with a time lag: concentrations were still high in 2009 (Fig. 2 and Fig. 6A), especially before the autumn sampling (Fig. 6D). These results suggest that the chemical recovery of the Morcille river was slower downstream (Fig. 6). Although we cannot rule out unlawful use of diuron on vineyard plots at the downstream section of the Morcille watershed, one could assume that chronic contamination of the Morcille by diuron several months after its ban can mainly be due to its release from contaminated soils through leaching, run-off or soil erosion (Reichenberger et al., 2007 and Alister and Kogan, 2010). The difference in contamination level between the intermediate and downstream stations might thus be related to a difference in the proportions of vineyard land areas between intermediate and downstream locations (52\% and $72 \%$ of the catchment area respectively; Pesce et al., 2010a). More generally, we note that despite a marked downward trend in the diuron exposure level over time, concentrations recorded at the intermediate and downstream stations were always above the quantification limit from February to December 2011 (i.e. more than two years after the diuron ban), with peak concentrations exceeding the WFD EQS value of $0.2 \mu \mathrm{g} \mathrm{L}-1$ at these two stations in spring (Fig. 2). This suggests that diuron is persistent in the environment and is liable to contribute to water pollution long after its last application (Louchart et al., 2001). Given their closely similar solubility properties (about $35 \mathrm{mg} \mathrm{L}-1$ at $20{ }^{\circ} \mathrm{C}$ ) and octanol-water partition coefficients $\left(\log \mathrm{P}\right.$ of about 2.8 at $\mathrm{pH} 7$ and $20{ }^{\circ} \mathrm{C}$ ), it is foreseeable that the persistence of diuron in the environment will be comparable to that of atrazine, another herbicide, which is still regularly detected in French surface waters ( Pesce et al., 2011b and Polard et al., 2011) despite its ban since ten years ago. 


\subsection{Did the evolution of diuron biodegradation potential of the Morcille's sediments reflect the decrease in diuron exposure levels in this stream?}

ANOVA indicated significant differences between years in MP15 $(\mathrm{F} 3,22=4.92, \mathrm{p}<0.001)$ and DT10 (F3,22 = 4.92, $\mathrm{p}<0.01)$ values, revealing a marked temporal trend over the survey period. Indeed, post hoc comparisons indicated that MP15 and DT10 were respectively significantly higher and lower in 2008 and 2009 than in 2011 (p < 0.05), suggesting a progressive decrease in diuron-mineralization potential. This was clearly detectable at the intermediate station, where values of MP15 (Fig. 4) and DT10 (Fig. 5) respectively decreased and increased over the years. Differences recorded between upstream and intermediate sediments were very low or non-existent from summer 2010 (MP15) or autumn 2010 (DT10). This suggests that the diuron contamination level in the Morcille was then too low to notably stimulate the diuron-mineralization potential at the intermediate section, or in other words, that the microbial recovery was complete in regard to this parameter. A similar decrease in diuron mineralization potential was observed in the downstream sediments, but interestingly, the difference between upstream and downstream MP15 and DT10 values was observed throughout the year 2010, suggesting a slower recovery of the sediments of the downstream station than of the intermediate station. In 2011, MP15 values markedly decreased downstream, and were always below $20 \%$, whatever the period of the year, with no apparent difference from upstream sediment samples (Fig. 4). Downstream DT10 values seemed also similar to the reference ones in 2011 (Fig. 5).

Comparing the diuron-mineralization potential observed in the contaminated section of the Morcille river before the diuron ban (autumn 2008) and three years later (autumn 2011), we found a notable recovery of microbial communities in the exposed sediments. Throughout this period, mean MP15 values decreased by $65 \%$ (downstream) to $82 \%$ (intermediate), and mean DT10 values increased from $143 \%$ (downstream) to $210 \%$ (intermediate). The data analysis revealed a clear relationship between the mean diuron exposure level and the diuronmineralizing potential both expressed as MP15 (Fig. 7A) or DT10 values (Fig. 7B). This relationship was best described by a logarithmic model, which revealed a significant correlation ( $p<0.05$, Fig. 7).

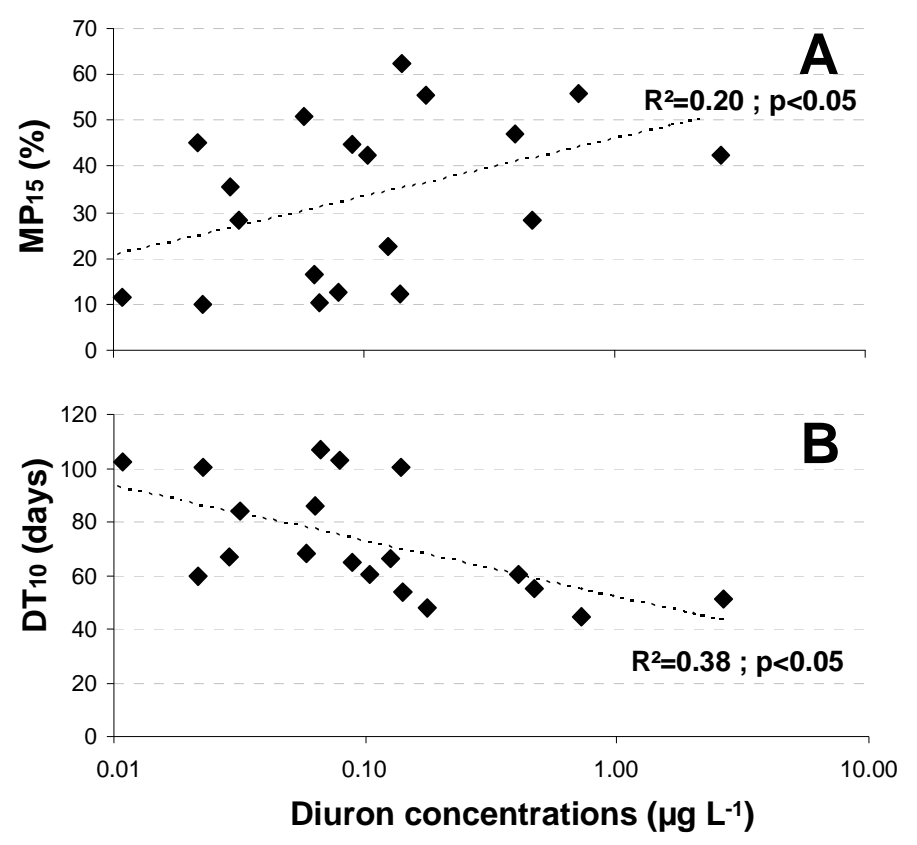

Fig. 7. Logarithmic relationship between mean diuron exposure during the three months preceding the sediment samplings and mean MP15 (A) and mean DT10 (B) values obtained with samples collected at the intermediate and downstream stations. 


\subsection{Advantages, limits and perspectives in the use of freshwater sediment biodegradation potential as an ecological indicator of the evolution of pesticide exposure effects}

Bioindicators supporting European legislation (e.g. the macrophyte biological index for rivers, the biological diatom index and the standardized global biological index) have been mainly defined to characterize trophic pressure in streams. Although standardized indicators are widely used to evaluate water quality, more research efforts are needed to design or propose innovative bioindicators specifically dedicated to chemical substances (Montuelle et al., 2010). The present study paves the way for using the estimation of sediment biodegradation potential for assessing spatio-temporal variations in diuron contamination and for gauging microbial recovery following a decrease in chronic diuron exposure. By extrapolation to various synthetic pesticides, it confirms that benthic microbial assemblages can potentially be useful biological indicators for the environmental monitoring of rivers and site-specific risk assessment, especially when focusing on microbial adaptation processes, such as the development of biodegradation (present study) or tolerance capacities (Pesce et al., 2010a) following chronic exposure to this kind of pollutant.

Up to now, assessment of biodegradation potential has mainly been used to address biodegradability of the pesticides as a part of the information required to file for approval of a pesticide according to ISO standard 15473 "Soil quality - Guidance on laboratory testing for biodegradation of organic chemicals in soil under anaerobic conditions" or to modified test of Sturm (OECD 301). Based on our results we can now propose a new standard using radiorespirometric approaches to address the exposure of microbial communities and their recoveries in different compartments of the environment (Philippot et al., 2012).

However, we note that the assessment of microbial biodegradation potential of synthetic pesticides using radiorespirometry is lengthy (generally several weeks) and is not always easy to implement, especially when using radiolabeled pesticides, which require specific authorization delivered by national radioprotection agencies, such as Agence de Sureté Nucléaire (ASN) in France, special laboratories and appropriate treatment of radioactive wastes. One alternative to this method could be the use of molecular approaches based on direct extraction of nucleic acids from environmental matrices and their subsequent analysis by PCR-based approaches to quantify the abundance of pesticide-degrading communities (Philippot et al., 2010). Specific information on the potential of biodegradation can be obtained by examining functional genes encoding enzymes involved in degradation pathways (Smith and Osborn, 2008 and Bombach et al., 2010). For example, in the case of diuron, Pesce et al. (2013) recently demonstrated that diuron mineralization kinetics obtained with soil samples were correlated to diuron-degrading genetic potentials estimated from the quantification of the abundance of the phenlylurea hydrolase gene puhB, confirming that degradation genes could be potential biomarkers for the detection of organic xenobiotics (Sipilä et al., 2008). In addition, Monard et al. (2013) recently showed that atrazine mineralizing ability of different soils was correlated to the expression level of atzD gene, coding for an enzyme responsible for s-triazine ring opening. However, one prerequisite for applying such approaches is knowledge of the degradation pathway and of the genes coding degrading enzymes. However, up to now, the number of known genes coding for pesticidedegrading enzymes, although increasing, is still limited, thereby restricting the application of this approach. Nonetheless, the recent publication of the ISO 11063 standard describing "a method to directly extract nucleic acid from soils" (Petric et al., 2011) and the recent adoption by ISO TC190/SC4/WG4 of new work item 17601 "Estimation of abundance of selected microbial gene sequences by quantitative realtime PCR from DNA directly extracted from soil" is paving the way for applying molecular tools targeting pesticide-degrading genes to monitor the recovery of microbial communities in different compartments of the environment. 


\section{Conclusions}

The present case study shows that the interdiction of diuron led to a progressive decrease in its concentrations in the Morcille river over a four-year survey period. However, diuron was still present in the water of the Morcille river three years after its ban. As a result of this decrease in the level of chronic exposure of the sediments, diuron-mineralizing potential also decreased, revealing a recovery of microbial communities in regard to this parameter. Our results show that the use of freshwater sediment biodegradation potential could be useful to assess microbial recovery following a decrease in chronic exposure to a pollutant, opening prospects for developing a new class of ecological indicator to monitor the recovery of the biological quality of water resources. In this way, the use of molecular approaches based on direct extraction of nucleic acids from environmental matrices and their subsequent analysis by PCR-based approaches to quantify the abundance of pesticide-degrading communities represents a promising perspective.

\section{Acknowledgments}

We thank Céline Guillemain of Irstea's Water Chemistry Laboratory (LAMA) for diuron analysis, Bernard Motte and Lucie Liger for field sampling support and ATT for English language editing.

F. Martin-Laurent and S. Pesce were supported by a project entitled 'entitled 'Amélioration de l'efficacité des zones tampons pour les pesticides et influence de labiodégradation naturelle' funded from the French National Office for the Aquatic Environment (ONEMA).

\section{References}

Alister, C., Kogan, M.., 2010. Rainfall effect on dissipation and movement of diuron and simazine in a vineyard soil. Planta daninha 28, 1059-1071.

Bombach, P., Richnow, H.H., Kästner, M., Fischer, A., 2010. Current approaches for the assessment of in situ biodegradation. Appl. Microbiol. Biotechnol. 86, 839-852.

Burns, A., Ryder, D.S., 2001. Potential for biofilms as biological indicators in Australian riverine systems. Ecol. Manag. Restor. 2, 53-63.

Coquery, M., Morin, A., Bécue, A., Lepot, B., 2005. Priority substances of the European water framework directive: analytical challenges in monitoring water quality. Trac-Trends Anal. Chem. 24, 117-127.

Delgado, C., Pardo, I., Garcia, L., 2012. Diatom communities as indicators of ecological status in Mediterranean temporary streams (Balearic Islands, Spain). Ecol. Indic. 15, 131139.

Dellamatrice, P.M., Monteiro R.T.R., 2004. Isolation of diuron-degrading bacteria from treated soil. Braz. Arch. Biol. Technol. 47, 999-1003

Dorigo, U., Leboulanger, C., Bérard, A., Bouchez, A., Humbert, J.F., Montuelle, B., 2007. Lotic biofilm community structure and pesticide tolerance along a contamination gradient in a vineyard area. Aquat. Microb. Ecol. 50, 91-102.

El-Sebai, T., Lagacherie, B., Cooper, J.F., Soulas, G., Martin-Laurent, F., 2005. Enhanced isoproturon mineralisation in a clay silt loam agricultural soil. Enhanced isoproturon mineralisation in a clay silt loam agricultural soil. Agron. Sustain. Dev. 25, 271-277.

Kalsch, W., Knacker, T., Robertz, M., Studinger G., Franke, C., 1998. Partitioning and mineralization of [14C]lindane in a laboratory sediment-water system. Environ. Toxicol. Chem. 17, 662-669.

Larsen, L., Sørensen, S,R., Aamand J., 2000. Mecocrop, isoproturon, and atrazine in and above a sandy aquifer: vertical distribution of mineralization potential. Environ. Sci. Technol. 34, 2426-2430. 
Louchart, X., Voltz, M., Andrieux, P., Moussa, R., 2001. Herbicide transport to surface waters at field and watershed scales in a Mediterranean vineyard area. Journal of Environ. Qual. 30, 982-991.

Monard, C., Martin-Laurent, F., Lima, O., Devers-Lamrani, M., Binet, F., (2013) Estimating the biodegradation of pesticide in soils by monitoring pesticide-degrading gene expression. Biodegradation, DOI 10.1007/s10532-012-9574-5

Morin, S., Pesce, S., Tlili, A., Coste, M., Montuelle, B., 2010. Recovery potential of periphytic communities in a river impacted by a vineyard watershed. Ecol. Indic. 10, 419426.

Montuelle, B., Dorigo, U., Bérard, A., Volat, B., Bouchez, A., Tlili, A., Gouy, V., Pesce, S., 2010. The periphyton as a multimetric bioindicator for assessing the impact of land use on rivers: an overview of the Ardières-Morcille experimental watershed. Hydrobiologia 657, 123-141.

Pesce, S., Fajon, C., Bardot, C., Bonnemoy, F., Portelli, C., Bohatier, J., 2008a. Longitudinal changes in microbial planktonic communities of a French river in relation to pesticide and nutrient inputs. Aquat. Toxicol. 86, 352-360.

Pesce, S., Bardot, C., Lehours, A.C., Batisson, I., Bohatier, J., Fajon, C., 2008b. Effects of diuron in microcosms on natural riverine bacterial community composition: new insight into phylogenetic approaches using PCR-TTGE analysis. Aquat. Sci. 70, 410-418.

Pesce, S., Martin-Laurent, F., Rouard, N., Montuelle, B., 2009. Potential for microbial diuron mineralisation in a small wine-growing watershed: from treated plots to lotic receiver hydrosystem. Pest. Manag. Sci. 65, 651-657.

Pesce, S., Margoum, C., Montuelle, B., 2010a. In situ relationships between spatio-temporal variations in diuron concentrations and phototrophic biofilm tolerance in a contaminated river. Water Res. 44, 1941-1949.

Pesce, S., Martin-Laurent, F., Rouard, N., Robin, A., Montuelle, B., 2010b. Evidence for adaptation of riverine sediment microbial communities to diuron mineralisation: incidence of run-off and soil erosion. J. Soil Sed. 10, 698-707.

Pesce, S., Bouchez, A., Montuelle, B., 2011a. Effects of organic herbicides on phototrophic microbial communities in freshwater ecosystems. Rev. Environ. Contam. Toxicol. 214, 87124.

Pesce, S., Morin, S., Lissalde, S., Montuelle B., Mazzella, N., 2011b. Combining polar organic chemical integrative samplers (POCIS) with toxicity testing to evaluate pesticide mixture effects on natural phototrophic biofilms. Environ. Pollut. 159, 735-741.

Pesce, S., Beguet, J., Rouard, N., Devers, M., Martin-Laurent, F., 2013. Response of a diurondegrading community to diuron exposure assessed by real-time quantitative PCR monitoring of phenylurea hydrolase A and B encoding genes. Appl. Microbiol. Biotechnol., DOI 10.1007/s00253-012-4318-3

Petrić, I., Philippot, L, Abbate, C., Bispo, A., Chesnot, T., Hallin, S., Laval, K., Lebeau, T., Lemanceau, P., Leyval, C., Lindström, K., Pandar, P., Romero, E., Sarr A., Schloter M., Simonet, P., Smalla, K., Wilke, B.M., Martin-Laurent, F. 2011. Inter-laboratory evaluation of the ISO standard 11063 "Soil quality - Method to directly extract DNA from soil samples". J. Microb. Meth. 84, 454-460.

Philippot, L., Abbate, C., Bispo, A., Chesnot, T., Hallin, S., Lemanceau, P., Lindström, K., Pandard, P., Romero, E., Schloter, M., Simonet, P., Smalla, K., Wilke, B.M., Petric, I., Martin-Laurent, F., 2010. Soil microbial diversity: an ISO standard for soil DNA extraction. J. Soil. Sed. 10, 1344-1345.

Philippot, L., Ritz, K., Pandard, P., Hallin, S., Martin-Laurent, F., 2012. Standardisation of methods in soil microbiology: progress and challenges. FEMS Microbiol. Ecol. 82, 1-10. 
Polard, T., Jean, S., Gauthier, L., Laplanche, C., Merlin, G., Sánchez-Pérez, J.M., Pinelli, E., 2011. Mutagenic impact on fish of runoff events in agricultural areas in south-west France. Aquat. Toxicol. 101, 126-134.

Rabiet, M., Margoum, C., Gouy, V., Carluer, N., Coquery, M., 2010. Assessing pesticide concentrations and fluxes in the stream of a small vineyard catchment - Effect of sampling frequency. Environ. Pollut. 158, 737-748.

Reichenberger, S., Bach, M., Skitschak, A., Frede, H.S., 2007. Mitigation strategies to reduce pesticide inputs into ground and surface water and their effectiveness; a review. Sci Total Environ 384, 1-35.

Ricart, M., Barceló, D., Geiszinger, A., Guasch, H., Alda, M.L.D., Romaní, A.M., Vidal, G., Villagrasa, M., Sabater, S., 2009. Effects of low concentrations of the phenylurea herbicide diuron on biofilm algae and bacteria. Chemosphere 76, 1392-1401.

Roubeix, V., Mazzella, N., Schouler, L., Fauvelle, V., Morin, S., Coste, M., Delmas, F., Margoum, C., 2011. Variations of periphytic diatom sensitivity to the herbicide diuron and relation to species distribution in a contamination gradient: Implications for biomonitoring. J. Environ. Monitor. 13, 1768-1774.

Sabater, S., Guasch, H., Ricart, M., Romani, A., Vidal, G., Klünder, C., Schmitt-Jansen, M., 2007. Monitoring the effect of chemical on biological communities. The biofilm as an interface. Anal. Bioanal. Chem. 387, 1425-1434.

Schneider, S., Lindstrøm, E.A., 2009. Bioindication in Norwegian rivers using nondiatomaceous benthic algae: The acidification index periphyton (AIP). Ecol. Indic. 9, 12061211.

Schuler, L.J., Rand, G.M., 2008. Aquatic risk assessment of herbicides in freshwater ecosystems of South Florida. Arch. Environ. Contam. Toxicol. 54, 571-583.

Sipilä, T.P., Keskinen, A.K., Åkerman, M.L., Fortelius, C., Haahtela, K., Yrjälä, K., 2008. High aromatic ring-cleavage diversity in birch rhizosphere: PAH treatment-specific changes of I.E. 3 group extradiol dioxygenases and $16 \mathrm{~S}$ rRNA bacterial communities in soil. ISME J. 2, 968-981.

Smith, C.J., Osborn, A.M., 2008. Advantages and limitations of quantitative PCR (Q-PCR)based approaches in microbial ecology. FEMS Microbiol. Ecol. 67, 6-20.

Soulas, G., 1993. Evidence for the existence of different physiological groups in the microbial community responsible for 2, 4-D mineralization in soil. Soil Biol. Biochem. 25, 443-449.

Sørensen, S.R., Bending, G.D., Jacobsen, C.S., Walker, A., Aamand, J., 2003. Microbial degradation of isoproturon and related phenylurea herbicides in and below agricultural fields. FEMS Microbiol. Ecol. 45, 1-11.

Stork, P.R., Bennett, F.R., Bell, M., 2008. The environmental fate of diuron under a conventional production regime in a sugarcane farm during the plant cane phase. Pest Manag. Sci. 64, 954-963.

Tadonléké, R.D., LeBerre, B., Perreau, F., Humbert, J.F., 2009. Responses of lake bacterioplankton activities and composition to the herbicide diuron. Aquat. Toxicol. 94, 103-113.

Tlili, A., Dorigo, U., Montuelle, B., Margoum, C., Carluer, N., Gouy, V., Bouchez, A., Bérard, A., 2008. Responses of chronically contaminated biofilms to short pulses of diuron: an experimental study simulating flooding events in a small river. Aquat. Toxicol. 87, 252263.

Tlili, A., Bérard, A., Roulier, J.L., Volat, B., Montuelle, B., 2010. PO43- dependence of the tolerance of autotrophic and heterotrophic biofilm communities to copper and diuron. Aquat. Toxicol. 98, 165-177. 
Toräng, L., Nyholm, N., Albrechtsen, H.J., 2003. Shifts in biodegradation kinetics of the herbicides MCPP and 2,4-D at low concentrations in aerobic aquifer materials. Environ. Sci. Technol. 37, 3095-3103.

Trinh, S.B., Hiscock, K.M., Reid, B.J., 2012. Mechanistic insights into the role of river sediment in the attenuation of the herbicide isoproturon. Environ. Pollut. 170, 95-101.

Wessels, J.S.C., Van der Veen, R., 1956. The action of some derivatives of phenylurethan and of 3-phenyl-1,1-dimethylurea on the Hill reaction. Biochem. Biophys. Acta 19, 548-549.

WFD, 2000. Directive 2000/60/EC of the European Parliament and of the Council establishing a framework for the Community action in the field of water policy (Water Framework Directive) adopted on 23.10.2000, published in the Official Journal (OJ L 237) on 22.12.2000. 